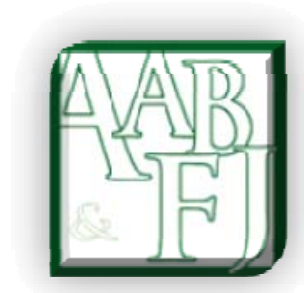

\title{
Factors Associated with the Social and Environmental Reporting of Australian Companies
}

\author{
Asit Bhattacharyya ${ }^{1}$
}

\begin{abstract}
:
Purpose: The objective of this study is twofold. Firstly, to examine the extent of social and environmental reporting in Australia, selected Global Reporting Initiative (GRI, 2002) social and environmental reporting guidelines were used to determine the extent; secondly, to analyse the association between firm characteristics and Levels of Social and Environmental reporting (SER), regression analysis was used to test the hypotheses.
\end{abstract}

Design/methodologylapproach: This study investigated SER practices of 47 small and large Australian companies drawn from five industries. Using seventeen social and eighteen environmental disclosure indicators, the study evaluates disclosure information presented in annual reports. Regression analysis was used to empirically examine the determinants of SER.

Findings: The results indicated that the extent of SER by Australian Companies was fairly low and the extent of total disclosure was significantly higher for large organisations in the Industrial Transport industry. Companies with negative return on total assets reported significantly higher social information. The extent of total disclosure was unrelated to an organisation's age and external auditor size.

Originality/value: The study provided a detailed analysis of the SER from the developing economy perspective using GRI social and environmental performance indicators.

Research limitations/implications: The study was limited by the use of selected GRI social and environmental indicators.

Practical and Social implications: The paper argues for greater social and environmental accounting researcher engagement with SEA practice. The study showed the gap and challenge still lies ahead in improving the quantity and quality of SEA from a developed economy perspective.

JEL Classification: M40

Keywords: Social reporting; environmental reporting, Global Reporting Initiative (GRI), Social and environmental reporting (SER)

\footnotetext{
${ }^{1}$ Asit.bhatta@newcastle.edu.au The University of Newcastle University drive, Callaghan, NSW 2308, Australia. Ph: +61 249216890
} 


\section{Introduction}

Social and environmental accounting research was widely promoted in the 1970s, lost its prominence in the 1980s, then re-emerged in the mid-to late 1990s (Deegan 2007), gaining attention particularly among researchers in Western countries (Guthrie \& Parker 1990; Gray et al. 1995a; Adams \& Kuasirikun 2004). There has been an increase in reporting on social and environmental issues by major corporations (Gray 2006). The volume of environmental legislation in Australia has increased but the requirement to disclose environmental information within annual reports, however, has not kept pace with the legislative reform (Deegan \& Rankin 1996). The amount of voluntary environmental disclosures in Australia is typically low and the disclosures are typically self-laudatory, with little or no negative disclosure (Deegan \& Gordon 1996). Even though disclosures have increased over time, there is considerable variety in the substance of what is reported (Burritt 2002). Prior studies (Rezaee et al. 1995; Schaltegger \& Burritt 2000; Burritt 2002) have articulated the need for standardisation of SER practices and use of the GRI framework (Schaltegger \& Burritt 2000; Burritt 2002; Holland \& Foo 2003; Raman 2006; Ho \& Taylor 2007; ), which is seen as the 'ideal' model. GRI reporting guidelines have also gained recognition and endorsement from various stakeholders, including intergovernmental agencies and supranational bodies, such as the European Union, United Nations, Organisation for Economic Co-operation and Development (OECD), and the World Economic Forum (Ho \& Taylor 2007).

SER increases transparency, which improves public image and relations with stakeholders (Robbins 2003). It also increases relationships with customers and employees (Baker 2001), who then increase the value of intangible assets of the company (Ernst \& Young 2002). Increased transparency enables companies to allocate resources more effectively and efficiently. Increased disclosure reduces regulatory cost and decreases legal liability of the firm (Robbins, 2003). Thus, it will improve competitiveness, profitability and share price of the organisation (CERES 2002). Through various empirical studies, authors have identified incentives for SER. Gray et al. (1996) provided an extensive list of incentives for SER. The list included ethics, individual commitment, accountability, legal code of practice, anticipated regulation, marketing, public image, defence to distract attention, influence perceptions, response to pressure, go ahead of/stay with competitors, prior commitment, and ethical investors to overcome fears of secrecy and to maintain a position of power and legitimisation. Various authors (Rahaman et al. 2004; Belal \& Owen 2007; Islam \& Deegan 2008) argued that consumer pressure or pressure from non government organisations or civil society groups are the driving force of SER in companies in developed economies. The driving force of SER of companies in emerging economies, however, which depend on foreign loans and aid, would be the external pressure from "powerful" international lending institutions (Rahman et al. 2004), pressure from particular stakeholders (such as international buyers) to upgrade their social performance, which shaped their social policy (Belal \& Owen 2007), and pressure from 'outside forces' via parent companies' instructions and pressure from international buyers (Islam \& Deegan, 2008). Most studies focus on environmental issues while social issues are not given due importance (Parker 2005). To this end, this study includes both social issues and environmental issues.

The objectives of this paper are twofold. Firstly, to examine the extent of social and environmental reporting in Australia, selected GRI (2002) social and environmental reporting guidelines have been used to determine how widely items with social and environmental impacts are being reported. The second objective was to analyse the association between firm characteristics and levels of SER in a developed economy context. Regression analysis was 
used to test hypotheses that link the variation in the extent of reporting to factors that are likely to influence SER.

The remainder of the paper is organised as follows: Section 2 presents the theoretical framework. Section 3 reviews prior literature and develops testable hypotheses. Section 4 discusses research design issues by presenting methodology, samples and data. Section 5 presents descriptive and empirical results, and Section 6 discusses the findings and concludes the paper.

\section{Theoretical framework}

Legitimacy theory, institutional theory, resource dependence theory and stakeholder theory provide important theoretical frameworks for social and environmental accounting research. These theories are generally alike because they share a similar ontological view, and the references of their terms are almost identical (Chen \& Robert 2010). These theories are considered to be system-oriented theories (Gray et al. 1995a, 1996; Chen \& Robert 2010), which assume that any organisation is influenced by the society in which it operates, and, in turn, the organisation also influences society. Organisations work within such interdependencies to reduce uncertainty and to ensure survival and growth (Chen \& Robert 2010).

Two major influences on companies' SER are acknowledged in this study: those related to the socio-political context within which companies operate, and those related to economic incentives. The theoretical framework adopted incorporates both influences, by adopting institutional theory perspectives, specifically legitimacy theory (e.g. Deegan 2002 Patten \& Crampton 2004; Deephouse \& Carter 2005), and resource-based perspectives (e.g. Hasseldine et al. 2005; Branco \& Rodrigues 2006). Some authors provide important studies in which similar combinations are attempted (e.g. Bansal 2005; Chen \& Robert 2010).

In this study, companies are considered to engage in some form of stakeholder management, driven by two different kinds of motivations. "Some companies believe that being seen as socially responsible will bring them a competitive advantage, allowing them to achieve better economic results. They expect that having good relations with their stakeholders will lead to increased financial returns by assisting in developing valuable intangible assets (resources and capabilities) which can be sources of competitive advantage because such assets can differentiate a company from its competitors" (Branco \& Rodrigues 2008, p. 686). These motivations are consistent with a resource-based perspective.

Other companies engage in CSR activities and disclosure because of external pressures (Rahman et al. 2004; Belal \& Owen 2007; Islam \& Deegan, 2008;). They either conform to what other companies do, because they believe that not doing so would harm them in terms of their profitability and survival, or respond to discrediting events, which they believe to be detrimental to their profitability and survival and must be addressed to mitigate their effects. "CSR activities and disclosure appear as mechanisms these companies use to act and be seen acting within the bounds of what is considered acceptable according to the expectations of stakeholders on how their operations should be conducted. Social responsibility activities and disclosure constitute mainly a legitimacy instrument used by a company to demonstrate its adherence to such expectations" (Branco \& Rodrigues 2008, p. 686). These motivations are consistent with social and political theory explanations, in particular legitimacy theory.

From a resource-based perspective the benefits of CSR are, to a great extent, related to their effect on corporate reputation (Branco \& Rodrigues 2006). SER is particularly important in enhancing the effects of CSR on corporate reputation. It might be considered a 
signal of improved social \& environmental conduct and hence reputation in those fields, as disclosure influences the external perception of reputation (Branco \& Rodrigues 2008).

Probably the most important weakness of resource-based perspectives is related to the lack of understanding they provide on the influence that the relationships between a company and its environment have on the company's success (Branco \& Rodrigues 2006). This is why a resource-based perspective is combined with legitimacy and stakeholder theories in this study. However, these theories are considered complementary rather than alternative or opposite (Gray et al. 1995a, p. 52).

The institutional perspective of legitimacy theory is one of the dominant theories in social disclosure research (e.g. Deegan 2002; Patten \& Crampton 2004; Chen \& Robert 2010). The focus of legitimacy theory's institutional perspective is on social legitimacy, which refers to the acceptance of a company by its social environment, and external constituents (Branco \& Rodrigues 2008). Legitimacy theory (Lindblom 1994; Suchman 1995) focuses on whether the value system of an organisation is congruent with the value system of society, and whether the objective of organisations is to meet social expectations. The theory states that legitimacy is a status or condition that is achieved when the value system of an organisation is congruent with the value system of the larger society. Organisations seek this status through the process of legitimation. The importance of social legitimacy comes from the theoretical assumption that companies are embedded in the social environment in which they operate, and that their performance and expectations are affected by the environment (Branco \& Rodrigues 2008). The company's success, even survival, is determined by this interface.

From such perspectives, SER is seen as one of the strategies used by companies to seek approval of their activities from society. "It is used to establish or maintain the legitimacy of the company because it may influence public opinion and public policy. Legitimacy theory suggests that SER provides an important way of communicating with stakeholders, to convince them that the company is fulfilling their expectations (even when actual corporate behaviour remains at variance with some of these expectations" (Branco \& Rodrigues 2008, p. 686).

Legitimacy theory and resource-based perspectives are believed to be useful as they can be conceived as using what Campbell et al. (2003, p. 559) call "the stakeholder metanarrative'. Thus, these perspectives can be explored by using stakeholder theory insights (Branco \& Rodrigues 2008). On the other hand, organisational legitimacy and organisational reputation are considered to have similar antecedents, social construction processes and consequences (Deephouse \& Carter 2005). This study refers to two interrelated concepts of legitimacy and reputation. Reputation is explored from a resource-based perspective and legitimacy is investigated from an institutional perspective.

\section{Literature Review and Hypothesis Development}

\subsection{General Review}

Although there are number of ways in which corporate social and environmental disclosures may occur (e.g. Guthrie \& Parker, 1990; Gray et al. 1995a, b), this study used the annual report disclosures as a basis for analysis, as this is the most common and mandatory document produced by companies on a regular basis (Belal 2000; Tilt 2001). Hence, making comparisons will be relatively easy (Tilt 2001). This approach is most commonly used as socially responsible activities are disclosed in the corporate annual report under the 'Directors Report', 'Managing Director's Report', 'Chairperson's Report', or 'General Manager's 
Report' (Ali \& Ahmed 2001). The annual report is the major communication medium and data source for researchers investigating the reasons underlying environmental disclosure (Gray et al. 1995a). Gray et al. (1995a) suggested that the annual report is the major medium for a company to promote itself, and that the inclusion of other information (such as environmental) along with financial data may indicate its relative importance. Rankin (1996) found that $68 \%$ of stakeholders sought environmental information from the annual report in the first instance and $43 \%$ sought this information from other sources. Members of environmental groups, such as Greenpeace and the Australian Conservation Foundation, considered annual reports to be the main information source about corporate environmental performance (Tilt 1994). Tilt (2001) found that $80 \%$ of companies used annual reports to disclose environmental information and commented that the annual report is still considered an appropriate medium for social and environmental disclosure.

The majority of SER studies focus on Western countries (Guthrie \& Parker 1990; Gray et al. 1995b, 1996; Deegan \& Gordon 1996; Gamble et al. 1996; Hackston \& Milne 1996; Adams \& Zutshi 2004; Ho \& Taylor 2007). These studies included longitudinal and crosssectional research. Few papers (Parker, 2005; Deegan \& Soltys 2007; Owen, 2008) have sought to review previous SER literature in its historical context. A brief description of studies related to the extent of SER and their determinants within a developed economy are as follows:

Table 1. Developed Economies' SER Research Related to their Extent and their Determinants

\begin{tabular}{|l|l|}
\hline Brief Description & SER studies \\
\hline $\begin{array}{l}\text { Predominantly quantitative studies } \\
\text { which indirectly explore corporate } \\
\text { motivations behind SER by } \\
\text { measuring the volume \& the extent } \\
\text { of disclosures }\end{array}$ & $\begin{array}{l}\text { Guthrie \& Parker 1990; Gray et al. 1995a; Deegan \& Gordan 1996; } \\
\text { Schaltegger \& Burritt 2000; Baker 2001; Adams 2002; Burritt 2002; } \\
\text { Deegan 2002; Solomon \& Lewis 2002; Holland \& Foo 2003; Tinker \& } \\
\begin{array}{l}\text { Studies which examined the } \\
\text { determinants of SER }\end{array}\end{array}$ \\
\hline
\end{tabular}

Although literature has highlighted the need for standardisation of SER practice using GRI guidelines, no published work has sought to examine the extent of SER based on these widely accepted GRI (2002) social and environmental reporting guidelines in Australia and India. As a result, both domestic and overseas investors are not fully aware of the extent and quality of SER within listed companies in these two countries. Using selected GRI (2002) social and environmental performance indicators this study tries to analyse quality and extent of SER of environmentally sensitive Australian companies. This study constructed disclosure indices to examine the quality and extent of SER, which serve as dependent variables of the regression analysis.

Several potential determinants of SER have been identified in the literature. Theoretical arguments yield predictions about the relation between disclosure and various firm characteristics, including agency costs, political costs, information asymmetry, and litigation costs. In reviewing SER studies, Gray et al. (1995a, pp. 49-50) conclude that CSR is: unsystematic; not related to profitability in the same period, though it may be related to lagged profits; does appear to be related to company size or types of industry, but the studies are not clear or consistent enough to determine such effects precisely. They also stated that CSR is related to the originating country of company, capital intensity, age, senior executives' attitudes, and strategic posture. Although most studies have looked at large companies, samples differ from study to study in terms of both size and industry 
composition. Differences in countries, time periods and explanatory variables make it difficult to generalise (Adams, 2002). The follows discussion reviews relevant literature on determinants of corporate disclosures and develops specific hypotheses, which are tested in this study.

\subsection{Size of the Reporting Entity}

Prior empirical studies have demonstrated an association between company size and SER (e.g. Gray et al. 1995a; Deegan \& Gordon 1996; Hackston \& Milne 1996; Adams et al. 1998; Cormier \& Gordon 2001; Ho \& Taylor 2007). A significant and positive relationship between firm size and the amount of positive disclosure were found by Deegan and Gordon (1996), Hackston and Milne (1996), Adams et al. (1998), Perry and Sheng (1999), and Ho and Taylor (2007). Both agency theory and legitimacy theory contain arguments for a size-disclosure relationship. Stanwick and Stanwick (1998) reported an inverse relationship between the firm size and firm's social responsiveness. Not all SER studies have supported a size-disclosure relationship however. $\mathrm{Ng}$ (1985) and Roberts (1992) found no relationship between company size and extent of reporting. Wallace and Naser (1995) suggest that smaller firms are more likely than larger firms to feel that greater disclosure would be detrimental to their competitive position. These non conclusive studies lead to the prediction in this paper that the extent of SER is not associated with firm size. Most small firms believe that their operations do not have significant environmental impact. The preceding discussion suggests the first hypothesis (stated in null form):

H0: There is no relationship or association between firm size and the extent of SER.

\subsection{Profitability}

Inchausti (1997) as cited in Ali et al. (2004) argues that management of profitable companies may disclose detailed information in the annual report, as they feel comfortable communicating this good news to the stock market in order to improve the firm's valuation. Adams (2002), with regards to the link between social disclosure and the economic performance of companies states that there is an unclear relationship to profit with SER. For example, Cowen et al. (1987) and Patten (1991) found no relationship to profit with SER in the same period, but Roberts (1992) found that social disclosure is related to strong economic performance in the previous period as measured by growth in return on equity. Some research has found a positive link between environmental and financial performance. In performing a direct comparison between 1,200 green and non-green companies, Edwards (1998) specifically mentioned that over two-third of "green" companies' performance is better than their non-green counterparts.

Empirical analysis provides mixed results in this issue in developed countries. Roberts (1992), Edwards (1998 and Stanwick and Stanwick (1998) found a positive relationship between a firm's social responsiveness and its financial performance, while Wallace and Naser (1995) and Ho and Taylor (2007) reported a negative relationship between profitability and the level of total disclosure. Cowen et al. (1987), Patten (1991), Gray et al. (1995a) and Hackston and Milne (1996) found no association between amount of disclosure and profitability. They also concluded that the size of the company and the industry in which it operates are significantly associated with amount of disclosure, whilst profitability is not. Given the mixed conclusions from prior empirical studies, we could expect a positive, negative, or even no relationship between corporate profitability and the extent of SER. So, we hypothesise, in null form, that:

H0: There is no association between corporate profitability and the extent of SER. 


\subsection{Industrial Membership}

The nature of a company's industry has been identified as a factor potentially affecting SER practices (Hackston \& Milne 1996). Dierkes and Preston (1997) argued that companies whose economic activities modify the environment, such as extractive industries, are more likely to disclose information about their environmental impact than companies in other industries. Comparison of one industry with another is done here, as the issue is whether companies whose economic activities modify the environment are more likely to have environmental disclosure.

A positive association between industry membership and SER has been found by several empirical studies (Roberts 1992; Gray et al. 1995a; Deegan \& Gordon 1996; Hackston \& Milne 1996,). Hackston \& Milne (1996) concluded that the size of organisation and the industry in which it operates are significantly associated with the amount of disclosure. There is strong evidence that industry membership is related to SER (Roberts 1992; Deegan \& Gordon 1996; Adams et al. 1998; Adams 2002; Ho \& Taylor 2007). The adverse selection argument also suggests that if a firm within an industry does not follow industry-wide disclosure practices, then this may be interpreted by the market that the firm is hiding bad news (Oyelere et al. 2003). The author expects that the same argument, therefore, test the following hypothesis in null form:

H0: There is no association between industry membership and the extent of SER.

\subsection{Age of the Reporting Entity}

Roberts (1992) found evidence that the age of the organisation might influence the level of SER. Gray et al. (1995a) also concluded that the age of the corporation may be related to corporate social reporting. No empirical studies have so far reported a significant relationship between age and level of SER. Roberts (1992) \& Gray et al. (1995a) were not conclusive about the association between age and level of SER.

Whether any systematic relationship between SER and the variables discussed above exists is open to question. Like the descriptive analyses, such relationships have been investigated in different time periods employing different sampling and measurement techniques (Hackston \& Milne 1996). Without systematic investigation using multiple measures and standardised techniques (replication studies), drawing firm conclusions about the existence of any such relationships is extremely difficult (Lindsay 1995 in Hackston \& Milne 1996). As prior empirical studies were inconclusive, we could expect a positive, negative, or even no relationship between the age of the reporting entity and the extent of SER. Thus, the author hypothesises, in null form, that:

H0: There is no association between age of the reporting entity and the extent of SER.

\subsection{Size of the Reporting Entity's Audit Firm}

Although the primary responsibility for preparing the annual report lies with company management, external auditors play a major role in the disclosure policies and practices of their clients. Watts and Zimmerman (1986), as cited in Ali et al. (2004), argues that large auditors exert a monitoring role in limiting the opportunistic behaviour by management. Fama and Jensen (1983) (cited in Ali et al. 2004) suggest that large audit firms have a greater incentive to report. If the client issues inadequate disclosure, this is likely to diminish the reputation of large audit firms more than small audit firms, which causes large audit firms to be more diligent. Further, large audit firms can exert more influence over the organisation's disclosure policies than that of small audit firms because of their large client base, which 
lessens the fee dependence on a specific client. Whilst these views were in relation to mandatory reporting by companies, similar arguments could be put forward for SER, which is largely a voluntary activity. These arguments also lead to the prediction in this paper that the extent of SER is positively associated with the size of the company's audit firm. Thus, the last hypothesis, in null form, is as follows:

H0: There is no association between size of the audit firm and the extent of SER.

\section{Research Design}

\subsection{Development and Measuring of Criteria}

GRI (2002) social and environmental performance indicators have been used to examine the level and quality of SER of the selected Australian companies. This paper used GRI to select the specific aspect (dependent variables) of the analysis. Thirty five (seventeen social and eighteen environmental) disclosure items are selected in order to determine the extent of SER. Disclosure items were selected based on an extensive review of prior academic literature and business surveys, including KPMG (2002, 2005), Holland and Foo (2003) and Ho and Taylor (2007). All thirty five selected disclosure indicators were included in the GRI (2002) social and environmental reporting guidelines. The seventeen social indicators (see Part A of Appendix I) were divided into four groups: (a) Employee; (b) Diversity, Opportunity and Human Rights; (c) Customer and Communities; and (d) Integrity and Ethics.

The eighteen environmental indicators (see Part B of Appendix II) were also grouped into four categories: (a) General; (b) Energy, Water and Materials; (c) Pollution and Waste Management; and (d) Others. All groupings were based on Ho and Taylor (2007). The indicators cover the five common environmental problems identified by the United Nation's International Standards of Accounting and Reporting (ISAR): (1) depletion of non-renewable energy resources; (2) depletion of freshwater resources; (3) global warming; (4) depletion of the ozone layer and (5) waste disposal (Ho \& Taylor 2007).

Following prior research (Hackston \& Milne 1996; Ali et al 2004; Raman 2006; Ho \& Tailor 2007), this study adopts a content analysis to collect and categorise relevant information from the whole annual report. Content analysis assumes that the content categories identified in the written messages of annual reports have manifested meanings (e.g. environment) that could, therefore, be categorised (Guthrie \& Parker 1990). Hence, content analysis has been widely employed in SER studies of annual reports (Guthrie \& Parker 1990; Deegan \& Gordan 1996; Belal 2000; Raman 2006). Some authors (Hackston \& Milne 1996; Ali et al. 2004; Ho \& Tailor 2007) used a quantitative value of one (if an item is disclosed) or zero (if not disclosed) to examine the extent of disclosure. This study also adopted a quantitative approach but different from that used by Hackston \& Milne (1996), Ali et al. (2004) and Ho \& Tailor (2007) to measure the extent and quality ${ }^{i}$ of disclosure. One problem with the quantitative approach is that some companies might be penalised by assigning a score of zero although the company is not expected to disclose that item because it is irrelevant due to the nature of operations or some other reason (Ali et al. 2004). Ali et al. (2004) and Cooke (1989) suggested that to mitigate this problem the whole annual report is to be read first to understand the nature of each organisation's operations and to determine whether a particular item is required to be reported or not. A similar approach (where the whole annual report was read first to understand the nature of each organisation's operations) was undertaken in this study to address the issue. Based on seventeen social and eighteen 
environmental indicators, a check list comprising thirty-five disclosure items has been developed. This scoring sheet has been applied to each organisation to determine the extent and quality of reporting within each country. The information has been coded assigning a quantitative value of zero, one or two to reflect the extent as well as quality of information. An indicator has been assigned a value of: (a) two, if it disclosed figures and tables of data (quantitative, to measure disclosure quality); (b) one, if it disclosed by short mention of topic (qualitative); and (c) zero, if it has not disclosed. Based on this scoring system, a tripartite disclosure index (incorporating social, environmental, and a combined social and environmental disclosure index) has been constructed for each organisation. The approach used to capture the essence and quality of Australian organisations' SER differs from prior studies. Firstly, information has been scored as zero, one and two (as mentioned above) by research assistants. To ensure consistency and relevance, and to avoid selection bias, $20 \%$ of the data was randomly chosen and coded separately by the author.

\subsection{Model Specification}

Following previous studies (Hackston \& Milne 1996; Ali et al. 2004; Ho \& Tailor 2007) a Multivariate Ordinary Least Squares (OLS) approach has been used, to determine which attributes are associated with SER and their significance level. The dependent variable is the quantity of the reporting of the sample companies measured by the selected social and environmental disclosure indicators. which has been calculated in terms of the disclosure index (DI) of reporting. Based on the review of the disclosure studies, the selected explanatory variables are: (a) size of the reporting entity (NA); (b) age of the reporting entity (ARE); (c) profitability (ROTA); (d) industry in which the company operates (IOC); and (e) size of the external auditor's firm (SAF). To address the question regarding determinants of SER the following multiple regression model is estimated:

$\mathrm{DIi}=\beta 0+\beta \mathrm{i} 1(\mathrm{ARE})+\beta \mathrm{i} 2(\mathrm{ROTA})+\beta \mathrm{i} 3(\mathrm{IOC})+\beta \mathrm{i} 4(\mathrm{NA})+\beta \mathrm{i} 5(\mathrm{SAF})$

Where:

DIi $=$ disclosure index on social factors, environmental factors or total (social and environmental combined);

$\mathrm{AREi}=$ age in years of the reporting entity based on the date of incorporation;

ROTAi $=$ return on total assets, measured by net operating profit to the book value of net assets for company $i$;

IOCi $=$ industry in which the company $\mathrm{i}$ operates (M. IND is used as a base (constant), 4 dummy variables for other four selected industries);

$\mathrm{NAi}=$ size of the reporting entity, measured as Log of net assets of the reporting entity at year end for company $i$;

$\mathrm{SAFi}$ = represents the size of reporting entity i's auditor's firm. One if audit firm is one of the big four (Pricewaterhouse Coopers, Deloitte Touche Tohmatsu, Ernst \& Young, KPMG), otherwise zero.

\subsection{Sample \& Data}

The final sample for analysis consisted of forty-seven annual reports. Annual reports of large ${ }^{2}$ and small publicly listed Australian companies were collected for the accounting year

\footnotetext{
${ }^{2}$ Large and small companies are determined based on their net assets. The top and bottom twenty five companies of an industry group given by 'Data Stream' are considered big and small respectively.
} 
2006-2007. The chosen industries groupings were: (a) Chemical; (b) Forestry and Paper; (c) Industrial Engineering; (d) Industrial Transport; and (e) Mining. The industries were selected based on social perceptions that companies operating in these industries were more likely to be considered "dirty" or environmentally damaging (Elkington 1994). Companies were then randomly selected from these industries based on size and industry distribution. The time period was chosen in order to allow sufficient time for adoption of the 2002 GRI reporting guidelines by the selected companies. Size categorisation was determined based on the net asset value of the organisation. The average net asset values of industries were calculated for each industry segment and then, keeping that average as the base, the top five and bottom five companies were chosen from each industry group. The companies and their industry groupings were chosen from Data Stream 4 (electronic database). Annual reports and information were collected from organisational and other related websites.

Data Stream, annual reports, and organisational and other related websites were the sources to obtain the data for the explanatory variables examined in the regression model, including: (a) size of the reporting entity (net asset); (b) profitability (return on total asset); (c) industrial membership; (d) age of the reporting entity (date of incorporation); and (e) size of the reporting entity's audit firm (big four or not). The distribution of the sample according to industry and size is presented in Table 2 below.

Table 2: Distribution of Sample According to Industry and Size

\begin{tabular}{|l|c|c|c|c|}
\hline Industry/Country & Large & Small & Number & $\%$ \\
\hline Chemicals & 5 & 4 & 9 & 19.15 \\
\hline Forestry \& Paper & 6 & 4 & 10 & 21.27 \\
\hline $\begin{array}{l}\text { Industrial } \\
\text { Engineering }\end{array}$ & 5 & 4 & 9 & 19.15 \\
\hline Industrial Transport & 5 & 4 & 9 & 19.15 \\
\hline Mining & 6 & 4 & 10 & 21.28 \\
\hline Grand Total & & & 47 & 100.00 \\
\hline
\end{tabular}

\section{Results}

\subsection{Descriptive Analysis}

Forty six companies revealed some form of social and environmental disclosure. Results of the descriptive analysis of the social and environmental reporting are presented in Appendix IIA, IIB \& Table 3. Appendix IIA reports on the results of social disclosures by assigning a score of zero, one or two. Furthermore, total disclosure scores were categorised into four categories: (a) Employee; (b) Diversity, Opportunity and Human Rights; (c) Customers and Communities; and (d) Integrity and Ethics. Forty six companies disclosed some form of social disclosure. Only three of the sampled companies disclosed information on 'Turnover of workforce'. Eighteen companies disclosed information on 'employee training and education'. Three to six companies disclosed information on 'diversity, opportunity and human rights'. Six companies disclosed information on 'integrity \& ethics' . Consistent with the findings of Hackston and Milne (1996) and Thompson and Zakaria (2004), Companies disclosed mainly on employee related issues, as opposed to customer and community issues.

Appendix IIB reports on the results of environmental disclosure scores classified under four categories: (a) General; (b) Energy, Water, and Materials; (c) Pollution and Waste Management; and (d) Others. 95\% of Australian companies made some form of environmental disclosure. The findings are inconsistent with the findings of similar studies, 
including Thompson and Zakaria (2004), which reported only 16\% disclosure by Malaysian companies. Most environmental disclosures by the companies are on 'energy, water, and materials', followed by the 'general' category, which constitutes mainly a company's statement of a corporate commitment to environmental protection. $31.9 \%$ of the companies disclosed information on energy usage and $93.6 \%$ of companies had not disclosed information on environmental contingent liabilities. Thirty eight companies disclosed information on the company's statement about a corporate commitment to environmental protection under the 'general' category, indicating that most companies were reporting qualitative and declarative information. Forty four companies did not disclose information on 'Identification of a contact person for providing additional information', indicating that companies are only interested in reporting good news they intended to do. These findings are consistent with the findings of Deegan \& Gordon (1996), in that the amount of voluntary environmental disclosures in Australia is low with little or no negative disclosure. Thirty eight of the companies disclosed information on indicators for 'strategies for the use of recycling product', thirty two on 'environmental impacts of principal products and services', thirty six on 'environmental accounting policies', and thirty seven on 'environmental expenditures'. Thirty three of the investigated companies disclosed information on 'fines/lawsuits/non-compliance incidents', indicating that they are taking the environmental reporting seriously.

Descriptive statistics of social, environmental and total (social and environmental combined) disclosure scores of the companies (Table 3) are presented bellow.

Table 3. Descriptive Statistics of Social, Environmental and Total (social and environmental combined) Disclosure Scores

\begin{tabular}{|l|c|c|c|c|}
\hline & Maximum & Mean & Std. Deviation & $\begin{array}{c}\text { Max. Score } \\
\text { Achievable }\end{array}$ \\
\hline Disclosure Score (Social) & 25 & 9.64 & 6.742 & 34 \\
Disclosure Score (Environmental) & 32 & 9.32 & 8.797 & 36 \\
Disclosure Score (Total) & 57 & 18.96 & 14.799 & 70 \\
Valid N & 47 & & & \\
\hline
\end{tabular}

Although results indicated that forty-five out of forty-seven companies disclosed some social and environmental information, it is evident from Appendix IIIB that the information disclosed under the environmental section were mainly within the 'energy, water and materials' category followed by the 'general' category, and that there is no consistency in reporting by the sample companies. It is evident from Appendix IB that the information disclosed under the environmental section is primarily general policy statements together with broad declarative statements such as;

"The Environmental committee assists the Board in the effective discharge of its responsibilities in relation to environmental matters arising out of activities within the company as they affect employees, contractors, visitors \& the communities in which it operates. The committee also reviews the company's compliance with the environment policy and legislation \& reviews environmental objectives, targets \& due diligence processes adopted by the company" (Orica Limited 2007, p. 18).

Apart from energy usage and water usage information, almost all other disclosures were qualitative in nature. It is evident from Appendix IIIB that very few companies disclose social information which is qualitative as well as quantitative in nature. 
Table 4 provides descriptive statistics for both dependent and explanatory variables in the regression model examining the determinants of SER. On average, a higher percentage of environmental items were disclosed in annual reports than were social items. In summary Australian companies achieved $27 \%$ of the total available score $(18.96 / 70)$, which is fairly low.

Table 4. Descriptive Statistics for Regression Variables

\begin{tabular}{|l|c|c|c|}
\hline Variables & Range & Mean & Std. Deviation \\
\hline $\begin{array}{l}\text { Total DI } \\
\text { (Social+Environ) }\end{array}$ & 57 & 18.89 & 14.638 \\
\hline DI (Social) & 25 & 9.64 & 6.742 \\
\hline DI (Environ) & 32 & 9.26 & 8.855 \\
\hline ARE & 93 & 12.83 & 20.630 \\
\hline ROTA & 3.930 & -9.168 & 5.698 \\
\hline C. IND. & 1 & .19 & .398 \\
\hline F\&P. IND. & 2 & .38 & .795 \\
\hline IE. IND. & 3 & .57 & 1.193 \\
\hline IT IND. & 4 & .77 & 1.591 \\
\hline M IND. & 5 & 1.06 & 2.068 \\
\hline NA & 8.858 & 2.138 & 1.601 \\
\hline SAF & 1 & .62 & .491 \\
\hline
\end{tabular}

$\mathrm{DI}_{\mathrm{I}} \quad=$ disclosure index on environmental factors or social factors or total of both factors

$\mathrm{NA}_{\mathrm{i}} \quad=$ logarithm of book value of net total assets of the reporting entity at year end

$\mathrm{AREi}=$ age in years of the reporting entity based on the date of incorporation

ROTA $_{i} \%=$ return on total assets, measured by net profit of the net total assets for company $i$

$\mathrm{SAF}_{\mathrm{I}} \quad=$ represents the size of reporting entity i's audit firm

$\mathrm{C}$ IND. $\quad=$ Chemical industry

F\&P IND. $=$ Forestry and Paper industry

IE IND. = Industrial Engineering industry

IT IND. = Industrial Transport industry

$\mathrm{M}$ IND. = Mining industry

\subsection{Analysis of Empirical Results}

Table 5 presents the multiple regression results. The $\mathrm{F}$ values for the three models are significant at the 0.01 level. These significant $F$ values suggest that the independent variables considered explain total SER, when taken together, and explain its categories when taken individually. However, this does not mean that each of the independent variables contributes to the explanation of the dependent variables. The adjusted $\mathrm{R}^{2} \mathrm{~s}$ suggest that approximately $38 \%$ (in the case of total reporting), $42 \%$ (in the case of social reporting), \& $27 \%$ (in the case of environmental reporting) of the variation in the SER scores between the companies can be explained by the independent variables included in the regression models. Although the adjusted $\mathrm{R}^{2 \mathrm{~s}}$ are reasonably low it is quite acceptable in accounting literature (Ali et al. 2004; Ho \& Taylor 2007).

Column (1) provides the results for total (social and environmental combined) disclosure. The coefficient on NA is positive and significant at the $1 \%$ level, indicating that the amount of total disclosure (social and environmental combined) is greater for larger firms after controlling for other factors that are likely to affect the extent of total reporting. The coefficient on NA is positive and significant at the $1 \%$ level for social disclosures as well as environmental disclosures, indicating that the amounts of social and environmental reporting separately are greater for larger firms. IT IND. is significantly associated with total (social and environmental combined) disclosure at the 5\% level, suggesting that companies under this industry disclosed more social \& environmental information. C. IND, F\&P. IND. IE. 
IND. \& M IND. are statistically insignificant suggesting that these industry memberships are not related to the amount of total disclosure (social and environmental combined). The coefficient on ARE is positive but not statistically significant at the conventional level (i.e., $10 \%$ or better). The coefficient on ROTA is negative and statistically significant only for social disclosure. The coefficient on SAF is positive and statistically insignificant (i.e. $10 \%$ or better). The results on multiple regression analysis for the determinant of SER model are presented in Table 5.

Table 5. Results on Multiple Regression Analysis for the Determinant of SER Model

$D I_{i}=\beta_{0}+\beta_{i 1}(A R E)+\beta_{i 2}\left(R O T A+\beta_{i 3}(I O C)+\beta_{i 4}(N A)+\beta_{i 5}(S A F)\right.$

\begin{tabular}{|c|c|c|c|c|c|c|}
\hline & \multicolumn{2}{|c|}{$\begin{array}{c}\text { (1) Total disclosure } \\
\text { (Social+ Environmental) }\end{array}$} & \multicolumn{2}{|c|}{ (2) Social disclosure } & \multicolumn{2}{|c|}{$\begin{array}{l}\text { (3) Environmental } \\
\text { disclosure }\end{array}$} \\
\hline Variables & Coeff & T-value & Coeff & T-value & Coeff & T-value \\
\hline (Constant) & & 1.163 & & 1.314 & & .876 \\
\hline ARE & .025 & .205 & .112 & .938 & -.043 & -.322 \\
\hline ROTA & -.174 & -1.183 & -.228 & $-1.608^{*}$ & -.113 & -.707 \\
\hline C. Ind & .152 & 1.030 & .179 & 1.254 & .115 & .715 \\
\hline F\&P. Ind & -.157 & -1.010 & -.153 & -1.020 & -.143 & -.842 \\
\hline IE. Ind & -.042 & -.278 & 043 & .297 & -.102 & -.623 \\
\hline IT. Ind & -.306 & $-2.086^{* *}$ & -.247 & $-1.740^{*}$ & -.318 & $-1.987 * *$ \\
\hline NA & .671 & $3.649 * * *$ & .809 & $4.549 * * *$ & .493 & $2.459 * * *$ \\
\hline SAF & .147 & .847 & .024 & .142 & .225 & 1.188 \\
\hline $\mathrm{R}^{2}$ & & .508 & & .539 & & .415 \\
\hline Adjusted $\mathrm{R}^{2}$ & & .388 & & .427 & & .272 \\
\hline Model's F-value & & $4.241 * * *$ & & $4.814 * * *$ & & $2.913^{* * *}$ \\
\hline
\end{tabular}

Column (1) provides evidence regarding the determinants of disclosure, but the results are based on total disclosures by combining social and environmental categories. As these two types of disclosures reflect different aspects of an organisation's activities, it is important to see whether the results vary across social and environmental disclosure categories. Regression results of social and environmental categories are provided in columns (2) and (3) of Table 5.

Column (2) reports results for the category of social disclosures. The coefficient on NA is positive and significant at the $1 \%$ level, providing evidence that a larger organisation is more likely to disclose social information. IT IND. is significant at the $10 \%$ level, indicating that Industrial Transport industry membership is an important factor in explaining the variation in the extent of social disclosure. More social information being reported by companies in this industry relative to other companies in the chosen five industries could be because of their environmental sensitivity. The coefficient on ROTA\% is negative and statistically significant at the $10 \%$ level, suggesting that companies with unfavourable profit performance disclose more social information. The coefficient on SAF is negative and statistically insignificant.

Column (3) presents results for environmental disclosure. IT IND. is significant at the $10 \%$ level, suggesting that industry membership is an important factor in explaining the variation in the extent of environmental reporting. C. IND, F\&P. IND. IE. IND. \& M IND. are statistically insignificant suggesting that these industry memberships are not related to 
environmental disclosure. This was an unexpected result as it is perceived that these industries are environmentally sensitive. The coefficient on NA is positive and significant at the $5 \%$ level, indicating that larger firms disclose more environmental information. ROTA is negatively associated with the level of environmental disclosure. This result is consistent with that for social disclosure, suggesting that companies with unfavourable profit performance disclose more social and environmental information. This could be to direct the attention of stakeholders away from financial performance while projecting that they are committed to social and environmental responsibility. However, the results are not statistically significant at the conventional level (i.e., 10\% or better). Also in line with the results on column (1), the coefficient on SAF is positive and statistically insignificant. In contrast to the results on columns (1) and (2), the coefficient in column 3 on ARE is negative but not statistically significant at the conventional level (i.e., $10 \%$ or better).

Overall, the evidence suggests that Australian companies are more driven by social (as opposed to environmental) disclosures. The overall explanatory power of the regression is higher for social disclosure (adjusted $\mathrm{R}^{2}=.427$ ) and lower for environmental disclosure (adjusted $\mathrm{R}^{2}=.272$ ). This suggests that the factors examined in this study are best in explaining the variation in the social disclosure practice.

\section{Discussion and Conclusion}

This study analyses the extent of SER and some factors which influence SER on a sample of Australian companies, using a theoretical framework which combines legitimacy theory and a resource-based perspective. According to this framework, managers increasingly need to consider SER as a signal of improved social and environmental conduct in those fields because disclosure influences the external perception of reputation. By demonstrating that they operate in accordance with social and ethical criteria, companies can build a reputation, whereas failing to do so can be a source of reputational risk (Branco \& Rodrigues 2008).

One objective of this analysis was the development of a total disclosure index (DI) for each sample organisation, which provides the extent and quality of reporting. There is evidence that suggests that quality and DI scores vary significantly across the thirty-five indicators examined. Evidence suggests that most of the selected companies do report some social and environmental information. However, the extent and quality of such reporting varied substantially. Companies place more emphasis on human resource development, product/service improvement and usage of energy and water. These findings are consistent with the findings of Hackston \& Milne (1996) on New Zealand and Raman (2006) on India, indicating that in this regard, an emerging country is not different from a developed country.

As Clarke and Gibson-Sweet (1999) suggest, some industries have a larger potential impact on the environment but are not as close to the final consumer, and the public is less aware of them. A company less well known to the public, and involved in activities with larger potential impact on the environment, would have less reason to justify its existence to society by means of community disclosures than a better known one (Branco \& Rodrigues 2008). This seems to be the case of companies in the Chemicals, Forestry and Paper, Industrial Engineering, and Mining sectors: a larger percentage of these disclose less community involvement information.

What was not expected, and seems more difficult to explain, are the results for environmental disclosures by companies in the environmentally sensitive sectors, such as Chemicals, Forestry and Paper, Industrial Engineering, and Mining. Companies in these industries do not disclose more environmental information than social information, as might be expected. Most of the mining companies published stand alone sustainability reports, and 
this could be the reason for the low disclosure of social and environmental information in the annual reports.

The results (Table 3, Appendix IIA, Appendix IIB) also indicate that quantity of the reporting by the sample and information disclosed is fairly low.

The regression analysis indicates that, for total disclosure (combining social and environmental categories), the extent of an organisation's reporting is significantly higher for companies with (a) a large size and (b) membership in the industrial transport industry. The results are consistent with other studies on developed economies, such as Deegan and Gordon (1996), Hackston and Milne (1996), Adams et al. (1998), Cormier and Gordon (2001) and Ho and Taylor (2007). With respect to industrial membership-disclosure relationship, the results support that there is an association between industry membership and the extent of SER. Industry affiliation was found to be related to SER by legitimacy theory studies. The findings are consistent with the theoretical framework and partially support the previous studies (e.g. Deegan \& Gordon 1996; Adams et al. 1998; Ho \& Taylor 2007) on developed economies. Only the industrial transport industry is associated with higher disclosure, although all other industries (Chemical, Forestry and Paper, Industrial Engineering, and Mining) tested are perceived as socially and environmentally sensitive. Both agency theory and legitimacy theory contain arguments for a size-disclosure relationship. The proponents of legitimacy theory emphasise the importance of communication but companies seem to be more interested in the strategic use of unilateral corporate communication such as environmental disclosure (Chen \& Roberts 2010). Consistent with previous studies, size and industry affiliation, which are considered as proxies for social visibility, have in general a positive relationship with total SER. These results are consistent with the expectations resulting from the theoretical framework and with previous SER studies.

The results on association between ROTA and the extent of reporting do not fully support the findings of Hackston \& Milne (1996) and Ho and Taylor (2007). Ho and Taylor (2007) found a negative and Hackston and Milne (1996) reported a positive relation. The result shows only a negative relationship with the extent of social reporting. The result also indicates an organisation's age in years is not associated with SER. This is not consistent with those prior findings (Gray et al. 1995a; Roberts 1992) that SER is related to age of organisation. The size of the auditor's firm was not associated with SER. Table 6 summarises the results on hypothesis testing.

Table 6: Summary of the Results from the Hypothesis Testing

\begin{tabular}{|l|l|l|l|}
\hline Variable & Hypothesis & Social & Environmental \\
\hline Size of the Reporting Entity & No association & Positive relation & Positive relation \\
Profitability & No association & Negative relation & Non- significant \\
Industrial Membership & No association & $\begin{array}{l}\text { Negative relation: } \\
\text { Industrial Transport } \\
\text { industry }\end{array}$ & $\begin{array}{l}\text { Negative relation: } \\
\text { Industrial Transport } \\
\text { industry }\end{array}$ \\
Age of the Reporting Entity & No association & Non- significant & Non- significant: \\
Size of the Reporting Entity's & No association & Non- significant & Non- significant \\
Audit Firm & No association & Non- significant & Non- significant \\
\hline
\end{tabular}

Evidence seems to suggest that companies with higher visibility demonstrate greater concern in improving corporate image through SER. In addition, in sectors with a high visibility among consumers there is greater concern for community involvement activities 
and disclosure. There is thus some support for the use of a combination of legitimacy theory with resource-based perspectives to explain SER by Australian companies.

The paper used GRI to select the specific aspect (dependent variables) of the analysis. The limitation of the paper is the use of selected GRI indicators only for dependent variables in the study. The regression results have propositions for GRI guidelines compliance. The disclosure index created by using GRI indicators and used in this study can be exploited by preparers in measuring the degree of compliance by their companies. The index can be updated by accumulating new guidelines and would help researchers undertaking future conformity analysis. Future research could include some other specific antecedents or substitute some of the used ones with a new one.

SER practices of listed companies are less subject to general contextual factors than those of unlisted companies. An interesting possible extension of this study would be to use a sample of companies which are not listed. Finally, the use of a larger sample would be an important way of adding new insights to the analysis of SER by emerging economies. 


\section{Acknowledgements}

An earlier version of this paper was presented at the $9^{\text {th }}$ CSEAR Australasian Conference and the internal Seminar of the University of Newcastle. Author of this article are very thankful to the participants of the $9^{\text {th }}$ CSEAR Australasian conference and internal seminar. Special thanks to the anonymous reviewers for their insightful comments and suggestions, which were very helpful in improving the manuscript.

\section{References:}

Adams, C, Hill, WY \& Roberts, C 1998, 'Corporate Social Reporting Practices in Western Europe: Legitimating Corporate Behaviour'? British Accounting Review, vol. 30, pp. 121. http://dx.doi.org/10.1006/bare.1997.0060

Adams, CA 2002, 'Internal organisational factors influencing corporate social \& ethical reporting: beyond current theorising', Accounting, Auditing \& Accountability Journal, vol.15, no 2, pp. 223-50. http://dx.doi.org/10.1108/09513570210418905

Adams, C \& Kuasirikun, N 2004, 'Corporate social accounting disclosure in Thailand', Accounting, Auditing \& Accountability Journal, vol.17, no. 4, pp. 629-660. http://dx.doi.org/10.1108/09513570410554588

Adams, C \& Zutshi, A 2004, 'Corporate Social Responsibility: Why Business Should Act Responsibly \& be Accountable', Australian Accounting Review, vol.14, no.3, pp. 31-39. http://dx.doi.org/10.1111/j.1835-2561.2004.tb00238.x

Ali, MJ \& Ahmed, K 2001, 'A Longitudinal Analysis of Corporate Social Disclosure: Recent Evidence from Australia', International Journal of Accounting \& Business Society, vol. 9, no.1, pp. $156-175$.

Ali, MJ, Ahmed, K \& Henry, D 2004, 'Disclosure compliance with national accounting standards by listed companies in South Asia', Accounting \& Business Research, vol. 34, no. 3, pp. 183-199

Baker, J 2001, 'Freedom of Association \& CSR', OECD Conference on Corporate Social Responsibility, 19 the June 2001.

Bansal, P 2005, 'Evolving Sustainability: A Longitudinal Study of Corporate Sustainable Development', Strategic Management Journal, vol. 26, no. 3, pp. 197-218. http://dx.doi.org/10.1002/smj.441

Belal, AR 2000, 'Environmental Reporting in Developing Countries: Empirical Evidence from Bangladesh', Eco-Management \& Audit, vol. 7, pp. 114-121. http://dx.doi.org/10.1002/1099-0925(200009)7:3<114::AID-EMA131>3.0.CO;2-E

Belal, AR, \& Owen, D 2007, 'The Views of Corporate Managers on the Current State of, and Future Prospects for, Social Reporting in Bangladesh: An Engagement Based Study', Accounting, Auditing \& Accountability Journal, vol. 20, no. 3, pp. 472-494. http://dx.doi.org/10.1108/09513570710748599

Branco, MC \& Rodrigues, LL 2006, 'Corporate Social Responsibility \& Resource Based Perspectives', Journal of Business Ethics, vol.69, no. 2, pp. 111-132. http://dx.doi.org/10.1007/s10551-006-9071-z

Branco, MC \& Rodrigues, LL 2008, 'Factors Influencing Social Responsibility Disclosure by Portuguese Companies', Journal of Business Ethics, vol. 69, no. 2, pp. 111-132. http://dx.doi.org/10.1007/s10551-006-9071-z 
Burritt, RL 2002, 'Environmental reporting in Australia: current practices \& issues for the future', Business Strategy \& the Environment, vol. 11, no. 6, pp. 391-406. http://dx.doi.org/10.1002/bse. 343

Campbell, D, Craven, B \& Shrives, P 2003, 'Voluntary Social Reporting in Three FTSE Sectors: A Comment on Perception \& Legitimacy', Accounting, Auditing \& Accountability Journal, vol. 16, no 4, pp. 558-581. http://dx.doi.org/10.1108/09513570310492308

Chen, JC \& Robert, RW 2010, 'Toward a More Coherent Understanding of the Organization-Society Relationship: A Theoretical Consideration for Social \& Environmental Accounting Research', Journal of Business Ethics, vol. 97, pp. 651-665 http://dx.doi.org/10.1007/s10551-010-0531-0

Clarke, J \& Gibson-Sweet, M 1999, 'The Use of Corporate Social Disclosures in the Management of Reputation \& Legitimacy: A Cross Sectoral Analysis of UK Top 100 Companies', Business Ethics: A European Review, vol.8, no 1, pp. 5-13. http://dx.doi.org/10.1111/1467-8608.00120

Coalition for Environmentally Responsible Economies (CERES 2002), Corporate Social Responsibility Profile of Ceres, CERES Conference 2002, April 17-19, Washington, U.S. <http://www.csrwire.com/members/12463-Ceres>

Cooke, TE 1989, 'Disclosure in the corporate annual reports of Swedish companies', Accounting \& Business Research, vol.19, pp. 113 -124.

Cormier, D \& Gordon, IM 2001, 'An examination of social \& environmental reporting strategies', Accounting, Auditing \& Accountability Journal, vol. 14, no 5, pp. 587-617. http://dx.doi.org/10.1108/EUM0000000006264

Cowen, SS, Ferreri, 1B \& Parker, DB, 1987, 'The impact of corporate characteristics on social responsibility disclosure: a typology and frequency - based Analysis', Accounting Organisations and Society, vol.12, no 2, pp. 111-122.

Data Stream 4 - 'Electronic data base', viewed 6 September, 2007).

Deegan, C \& Gordan, B 1996, 'A study of the Environmental Disclosure Policies of Australian Corporations', Accounting \& Business Research, vol. 23, no 3, pp. 187-199.

Deegan, C \& Rankin, M 1996, 'Do Australian companies report environmental news objectively? An analysis of environmental disclosures by firms prosecuted successfully by the Environmental Protection Authority', Accounting, Auditing \& Accountability Journal, vol. 9, no 2, pp. 50-67. http://dx.doi.org/10.1108/09513579610116358

Deegan, C 2002, 'The legitimising effect of social \& environmental disclosures-a theoretical foundation', Accounting, Auditing \& Accountability Journal, vol. 15, no 3, pp. 282-311. http://dx.doi.org/10.1108/09513570210435852

Deegan, C 2007, Australian Financial Accounting, McGraw-Hill, Sydney.

Deegan, C \& Soltys, S 2007, 'Social accounting research: An Australasian perspective', Accounting Forum, vol. 31, no 1, pp. 73-89. http://dx.doi.org/10.1016/j.accfor.2006.11.001

Deephouse, DL \& Carter, SM 2005, 'An Examination of Differences Between Organizational Legitimacy \& Organizational Reputation', Journal of Management Studies, vol. 42, no 2, pp. 329-360. http://dx.doi.org/10.1111/j.1467-6486.2005.00499.x

Dierkes, M \& Preston, LE 1977, 'Corporate social accounting and reporting for the physical environment: a critical review and implementation proposal', Accounting, Organisations and Society, vol. 2, no.1, pp. 3-22.

Edwards, D, 1998, 'The Link between Company Environmental and Financial performance', London: Earthscan. 
Elkington, J 1994, 'Towards the sustainable corporation: Win-win-win business strategies for sustainability', California Management Review, vol. 36, no 2, pp. 90. http://dx.doi.org/10.2307/41165746

Ernst \& Young 2002, Corporate Social Responsibility, viewed 23 April, 2007, $<$ http://www.ey.com/global/Content.nsf/Australia $>$

Fama, EF \& Jensen, MC 1983, 'Separation of Ownership \& control', Journal of Law \& Economics, vol. 25, pp. 301-325. http://dx.doi.org/10.1086/467037

Gamble, G, Hsu, K, Jackson, C \& Tollerson, C 1996, 'Environmental Disclosure in Annual Reports: An International Perspective', International Journal of Accounting, vol. 31, no 3, pp. 293-331. http://dx.doi.org/10.1016/S0020-7063(96)90022-9

Global Reporting Initiative, (GRI 2002), 'Sustainability Reporting Guidelines', viewed 27 November, 2007, <http//www.globalreporting.org/guidelines/2002.asp>

Gray, R, Kouhy, R \& Lavers, S 1995a, 'Corporate social \& environmental reporting: a review of the literature \& a longitudinal study of UK disclosure', Accounting, Auditing \& Accountability Journal, vol. 8, no 2, pp. 47-77. http://dx.doi.org/10.1108/09513579510146996

Gray, R, Kouhy, R \& Lavers, S 1995b, 'Methodological themes: Constructing a research database of social \& environmental reporting by UK companies', Accounting, Auditing \& Accountability ${ }_{2}$ vol. 8, no 2, pp. 78-101. http://dx.doi.org/10.1108/09513579510086812

Gray, R, Owen, D, \& Adams, C 1996, Accounting and Accountability: Changes and Challenges in Corporate Social and Environmental Reporting, Prentice Hall, Hemel Hempstead.

Gray, R 2006, 'Social, environmental \& sustainability reporting \& organisational value creation? Whose value? Who's Creation'? Accounting, Auditing \& Accountability Journal, vol. 19, no 6, pp. 793-819. http://dx.doi.org/10.1108/09513570610709872

Guthrie, J \& Parker, LD 1990, 'Corporate social disclosure practice: a comparative international analysis', Advances in Public Interest Accounting, vol. 3, no 2, pp. 159176.

Hackston, D \& Milne, MJ 1996, 'Some Determinant of Social \& Environmental Disclosures in New Zeal\& Companies', Accounting, Auditing \& Accountability Journal, vol. 9, no 1, pp. 77-108 http://dx.doi.org/10.1108/09513579610109987

Hasseldine, J, Salama, AI \& Toms, JS 2005, 'Quantity Versus Quality: The Impact of Environmental Disclosures on the Reputations of UK PLCS', The British Accounting Review, vol. 37, no 2, pp. 231-248. http://dx.doi.org/10.1016/j.bar.2004.10.003

Ho, LJ \& Taylor, ME 2007, 'An Empirical Analysis of Triple Bottom Line Reporting \& its Determinants: Evidence from the United States \& Japan', Journal of International Management \& Accounting, vol. 18, no 2, pp. 123-150.

Holland, L \& Foo, YB 2003, 'Differences in environmental reporting practices in the UK \& the US: The Legal \& Regulatory Context', The British Accounting Review, vol. 35, pp. 1-18. http://dx.doi.org/10.1016/S0890-8389(02)00127-0

International Standards of Accounting \& Reporting (ISAR), viewed 22, December, 2008, $<$ http://www.unctad.org/Templates/Startpage.asp?intItemID $=2531>$

Islam, MA \& Deegan, C 2008, 'Motivations for an organisation within a developing country to report social responsibility information: Evidence from Bangladesh', Accounting, Auditing \& Accountability Journal, vol. 21, no 6, pp. 850 - 874.

KPMG International Survey of Corporate Responsibility reporting (2002), De Meern, the Netherl\&s: KPMG Global Sustainability Services, 2002, viewed 2 January, <http/ www.eldis.org/static/DOC18813.htm> 
KPMG International Survey of Corporate Responsibility reporting (2005), viewed 2 January, $<\mathrm{http} /$ www.eldis.org/static/DOC18813.htm>.

Lindblom, CK 1994, 'The Implications of Organizational Legitimacy for Corporate Social Performance \& Disclosure', in Critical Perspectives on Accounting Conference, New York., viewed 8 November 2007, <http://www.st-andrews.ac.uk/csear/what-issea/sage/vol-2/>

Lindsay, RM 1995, 'Reconsidering the status of tests of significance: an alternative criterion of adequacy', Accounting, Companies \& Society, vol. 35, no 1, pp. 35-53.

$\mathrm{Ng}$, LW 1985, 'Social responsibility disclosures of selected New Zealand companies for 1981, 1982 and 1983', Occasional paper no. 54, Massey University, Palmerston North.

Orica Limited - Annual report 2007, p. 18). http/www.orica.com.au/

Owen, D (2008), 'Chronicles of wasted time? A personal reflection on the current state of, \& future prospects for, social \& environmental accounting research', Accounting, Auditing \& Accountability Journal, vol. 21, no 2, pp. 240-267. http://dx.doi.org/10.1108/09513570810854428

Oyelere, P, Laswad, F \& Fisher, R 2003, 'Determinants of Internet Financial Reporting by New Zeal\& Companies', Journal of International Financial Management \& Accounting, vol.14, no 1, pp. 26-63. http://dx.doi.org/10.1111/1467-646X.00089

Parker, L. D. 2005, 'Social \& environmental accountability research A view from the commentary box', Accounting, Auditing \& Accountability Journal ${ }_{2}$ vol. 18, no 6, pp. 842-860. http://dx.doi.org/10.1108/09513570510627739

Patten, DM 1991, 'Exposure, Legitimacy, and Social Disclosure', Journal of Accounting and Public policy, vol.10, no 4, pp. 297-308.

Patten, DM \& Crampton, W 2004, 'Legitimacy \& the Internet: An Examination of Corporate Web Page Environmental Disclosures', Advances in Environmental Accounting \& Management, vol. 2, pp. 31-57. http://dx.doi.org/10.1016/S1479-3598(03)02002-8

Perry, M \& Sheng, TT 1999, 'An overview of trends related to environmental reporting in Singapore', Environmental Management \& Health, vol.10, no 5, pp. 310-320. http://dx.doi.org/10.1108/09566169910289667

Rahaman, AS, Lawrence, S \& Roper, J 2004, 'Social and environmental reporting at the VRA: institutionalised legitimacy or legitimation crisis'? Critical Perspectives on Accounting, vol. 15, no. 1,pp. 35-56. http://dx.doi.org/10.1016/S1045-2354(03)00005-4

Raman, SR 2006, 'Corporate Social Reporting in India - A View from the Top', Global Business Review, vol. 7, no 2, pp. 313 - 324. http://dx.doi.org/10.1177/097215090600700208

Rankin, M 1996, Corporate Reporting-The Green Gap, Institute of Chartered Accountants in Australia, Sydney.

Rezaee, Z, Szendi, J \& Aggarwal, R 1995, 'Corporate governance \& accountability for environmental concerns', Managerial Auditing Journal, vol. 10, no 8, pp. 27-33. http://dx.doi.org/10.1108/02686909510093598

Robbins, SP, Bergman, R, Stagg, I \& Coulter, M 2003. Management, Prentice Hall, Sydney.

Roberts, RW 1992, 'Determinant of corporate social responsibility disclosure: an application of stakeholder theory', Accounting Companies \& Society, vol. 17, no 6, pp. 595-612. http://dx.doi.org/10.1016/0361-3682(92)90015-K

Schaltegger, S \& Burritt, RL 2000, Contemporary Environmental Accounting, Greenleaf, Sheffield. 
Solomon, A \& Lewis, L 2002, 'Incentives \& disincentives for corporate environmental disclosure', Business Strategy \& the Environment, vol. 11, no 3, pp. 154. http://dx.doi.org/10.1002/bse.328

Stanwick, SD \& Stanwick, PA 1998, 'Corporate social responsiveness: An empirical examination using the environment', International Journal of Commerce \& Management, vol. 8, no 3, pp. 26 - 40. http://dx.doi.org/10.1108/eb047373

Suchman, MC 1995, 'Managing Legitimacy: Strategic \& Institutional Approaches', Academy of Management Review, vol. 20, no 3, pp. 571-610.

Thompson, P \& Zakaria, Z 2004, 'Corporate Social Responsibility Reporting in Malaysia: Progress \& Prospects', The Journal of Corporate Citizenship, vol. 13, pp. 125.

Tilt, CA 1994, 'The influence of external pressure groups on corporate social disclosure: some empirical evidence', Accounting, Auditing \& Accountability journal, vol. 7, no. 4, pp. 56-71. http://dx.doi.org/10.1108/09513579410069849

Tilt, CA (2001), 'The content \& disclosure of Australian corporate environmental policies', Accounting, Auditing \& Accountability Journal, vol.14, no 2, pp. 190. http://dx.doi.org/10.1108/09513570110389314

Tinker, T \& Gray, R 2003, 'Beyond a critique of pure reason: From policy to politics to praxis in environmental \& social research', Accounting, Auditing \& Accountability Journal, vol.16, no 16(5), pp. 727-761. http://dx.doi.org/10.1108/09513570310505952

Vanstraelen, A, Zarzeski, M \& Robb, S 2003, 'Corporate Non-financial Disclosure practices \& Financial Analyst Forecast Across Three European Countries', Journal of International Financial Management \& Accounting, vol.14, no 3, pp. 249-278. http://dx.doi.org/10.1111/1467-646X.00098

Wallace, RS \& Naser, K 1995, 'Firm specific determinants of the comprehensiveness of mandatory disclosure in the corporate annual reports of firms listed on the stock exchange of Hong Kong', Journal of Accounting \& Public Policy, vol.14, pp. 311-68. 


\section{Appendix I}

\section{Social \& Environmental Indicators used for Evaluating the Extent \& Quality of Social \& Environmental Reporting}

\section{(A) List of Social disclosure Indicators}

Employee

(1) Company's statement of a corporate commitment to its shareholders and for society as a whole

(2) Number of employees and their geographic distribution

(3) Turnover of workforce

(4) Levels of employee education

(5) Employee benefits concerning health care, disability, or retirement

(6) Employee health and safety information such as number of lost workdays, accidents or deaths

(7) Employee training and education

\section{Diversity, Opportunity \& Human Rights}

(8) Any mention of policies or programs addressing workplace harassment and discrimination

(9) Number or percentage of women and minorities in the organisation

(10) Policies or procedures dealing with human rights issues

\section{Customers \& Communities}

(11) Any mention of policies for preserving customer health and safety

(12) Company's involvement in community activities

(13) Policies for prioritising local employment

\section{Integrity \& ethics}

(14) Policies for compliance mechanisms for bribery and corruption

(15) Policies for preventing anti-competitive behaviour

(16) Policies for consumer privacy

(17) Provision of business code

\section{(B) List of Environmental Disclosure Indicators}

\section{General}

(1) Company's statement of a corporate commitment to environmental protection

(2) Environmental audit

(3) Environmental awards

(4) Incorporation of environmental concerns into business decisions (e.g., green purchasing)

(5) Identification of a contact person for providing additional information

\section{Energy, Water, and Materials}

(6) Energy usage information

(7) Encouragement of renewable energy consumption

(8) Water usage information

(9) Information concerning the materials that are re-cycled or re-used

(10) Any mention of strategies for the use of recycling product

\section{Pollution \& waste management}

(11) Information about the sources, types and remedy procedures of emissions

(12) Pollution impacts of transportation equipment used for logistical purposes

(13) Environmental impacts of principal products and services

(14) Discussion on the amount, types of wastes and methods of waste management

Others

(15) Any mention of environmental accounting policies

(16) Environnemental expéditeurs

(17) Fines/lawsuits/non-compliance incidents

(18) Environmental contingent liabilities 


\section{Appendix II}

Appendix IIA Descriptive for Social Disclosure Indicators in Indian and Australian Companies

\begin{tabular}{|c|c|c|c|}
\hline Disclosure Indicators & Score & Frequency & $\%$ \\
\hline \multicolumn{4}{|l|}{ Employee } \\
\hline $\begin{array}{l}\text { 1) Company's statement of a corporate } \\
\text { commitment to its shareholders \& for } \\
\text { society as a whole }\end{array}$ & $\begin{array}{l}0 \\
1 \\
2\end{array}$ & $\begin{array}{l}6 \\
10 \\
31\end{array}$ & $\begin{array}{l}12.8 \\
21.3 \\
66.0\end{array}$ \\
\hline $\begin{array}{l}\text { 2) Number of employees \& their geographic } \\
\text { distribution }\end{array}$ & $\begin{array}{l}0 \\
1 \\
2\end{array}$ & $\begin{array}{l}25 \\
1 \\
21\end{array}$ & $\begin{array}{l}53.2 \\
2.1 \\
44.7\end{array}$ \\
\hline 3) Turnover of workforce & $\begin{array}{l}0 \\
1 \\
2\end{array}$ & $\begin{array}{l}44 \\
1 \\
2\end{array}$ & $\begin{array}{l}93.6 \\
2.1 \\
4.3\end{array}$ \\
\hline 4) Levels of employee education & $\begin{array}{l}0 \\
1 \\
2\end{array}$ & $\begin{array}{l}33 \\
2 \\
12\end{array}$ & $\begin{array}{l}70.2 \\
4.3 \\
25.5\end{array}$ \\
\hline $\begin{array}{l}\text { 5) Employee benefits concerning health care, } \\
\text { disability, or retirement }\end{array}$ & $\begin{array}{l}0 \\
1 \\
2\end{array}$ & $\begin{array}{l}16 \\
7 \\
24\end{array}$ & $\begin{array}{l}34.0 \\
14.9 \\
51.1\end{array}$ \\
\hline $\begin{array}{l}\text { 6) Employee health \& safety information such } \\
\text { as number of lost workdays, accidents or } \\
\text { deaths }\end{array}$ & $\begin{array}{l}0 \\
1 \\
2\end{array}$ & $\begin{array}{l}18 \\
15 \\
14\end{array}$ & $\begin{array}{l}38.3 \\
31.9 \\
29.8\end{array}$ \\
\hline 7) Employee training \& education & $\begin{array}{l}0 \\
1 \\
2\end{array}$ & $\begin{array}{l}29 \\
4 \\
14 \\
\end{array}$ & $\begin{array}{l}61.7 \\
8.5 \\
29.8 \\
\end{array}$ \\
\hline \multicolumn{4}{|l|}{ Diversity, opportunity \& human rights } \\
\hline $\begin{array}{l}\text { 8) Any mention of policies or programs } \\
\text { addressing workplace harassment \& } \\
\text { discrimination }\end{array}$ & $\begin{array}{l}0 \\
1 \\
2\end{array}$ & $\begin{array}{l}41 \\
1 \\
5 \\
\end{array}$ & $\begin{array}{l}87.2 \\
2.1 \\
10.6 \\
\end{array}$ \\
\hline $\begin{array}{l}\text { 9) Number or percentage of women \& } \\
\text { minorities in the organization }\end{array}$ & $\begin{array}{l}0 \\
1 \\
2\end{array}$ & $\begin{array}{l}41 \\
2 \\
4 \\
\end{array}$ & $\begin{array}{l}87.2 \\
4.3 \\
8.5\end{array}$ \\
\hline $\begin{array}{l}\text { 10) Policies or procedures dealing with } \\
\text { human rights issues }\end{array}$ & $\begin{array}{l}0 \\
1 \\
2 \\
\end{array}$ & $\begin{array}{l}44 \\
1 \\
2 \\
\end{array}$ & $\begin{array}{l}93.6 \\
2.1 \\
4.3 \\
\end{array}$ \\
\hline \multicolumn{4}{|l|}{ Customers \& communities } \\
\hline $\begin{array}{l}\text { 11) Any mention of policies for preserving } \\
\text { customer health \& safety }\end{array}$ & $\begin{array}{l}0 \\
1 \\
2 \\
\end{array}$ & $\begin{array}{l}39 \\
4 \\
4 \\
\end{array}$ & $\begin{array}{l}83.0 \\
8.5 \\
8.5 \\
\end{array}$ \\
\hline $\begin{array}{l}\text { 12) Company's involvement in } \\
\text { community activities }\end{array}$ & $\begin{array}{l}0 \\
1 \\
2\end{array}$ & $\begin{array}{l}29 \\
3 \\
15 \\
\end{array}$ & $\begin{array}{l}61.7 \\
6.4 \\
31.9 \\
\end{array}$ \\
\hline $\begin{array}{l}\text { 13) Policies for prioritizing local } \\
\text { employment }\end{array}$ & $\begin{array}{l}0 \\
1 \\
2 \\
\end{array}$ & $\begin{array}{l}37 \\
4 \\
6 \\
\end{array}$ & $\begin{array}{l}78.7 \\
8.5 \\
12.8 \\
\end{array}$ \\
\hline \multicolumn{4}{|l|}{ Integrity \& ethics } \\
\hline $\begin{array}{l}\text { 14) Policies for compliance mechanisms for } \\
\text { bribery \& corruption }\end{array}$ & $\begin{array}{l}0 \\
1 \\
2 \\
\end{array}$ & $\begin{array}{l}37 \\
3 \\
7 \\
\end{array}$ & $\begin{array}{l}78.7 \\
6.4 \\
14.9 \\
\end{array}$ \\
\hline $\begin{array}{l}\text { 15) Policies for preventing anti- } \\
\text { competitive behaviour }\end{array}$ & $\begin{array}{l}0 \\
1 \\
2 \\
\end{array}$ & $\begin{array}{l}41 \\
2 \\
4 \\
\end{array}$ & $\begin{array}{l}87.2 \\
4.3 \\
8.5 \\
\end{array}$ \\
\hline Policies for consumer privacy & $\begin{array}{l}0 \\
1 \\
2 \\
\end{array}$ & $\begin{array}{l}44 \\
1 \\
2 \\
\end{array}$ & $\begin{array}{l}93.6 \\
2.1 \\
4.3 \\
\end{array}$ \\
\hline Provision of business code & $\begin{array}{l}0 \\
1 \\
2 \\
\end{array}$ & $\begin{array}{l}11 \\
14 \\
22 \\
\end{array}$ & $\begin{array}{l}23.4 \\
29.8 \\
46.8 \\
\end{array}$ \\
\hline
\end{tabular}

Note: $0=$ no disclosure, $1=$ qualitative disclosure, $2=$ quantitative disclosure 


\section{Appendix IIB.}

Descriptive for Environmental Disclosure Indicators in Indian and Australian Companies

\begin{tabular}{|l|c|c|c|}
\hline Disclosure Indicators & Score & Frequency & $\%$ \\
\hline General & & & \\
\hline 1. Company's statement of a & 0 & 9 & 19.1 \\
corporate commitment to & 1 & 11 & 23.4 \\
environmental protection & 2 & 27 & 57.4 \\
\hline 2. Environmental audit & 0 & 30 & 63.8 \\
& 1 & 9 & 19.1 \\
& 2 & 8 & 17.0 \\
\hline 3. Environmental awards & 0 & 41 & 87.2 \\
& 1 & 0 & 0 \\
& 2 & 6 & 12.8 \\
\hline 4. Incorporation of environmental & 0 & 31 & 66.0 \\
concerns into business decisions & 1 & 1 & 2.1 \\
(e.g., green purchasing) & 2 & 15 & 31.9 \\
\hline 5. Identification of a contact person & 0 & 44 & 93.6 \\
for providing additional & 1 & 1 & 2.1 \\
information & 2 & 2 & 4.3 \\
\hline Energy, water, \& materials & & & \\
\hline 6. Energy usage information & 0 & 32 & 68.1 \\
& 1 & 6 & 12.8 \\
& 2 & 9 & 19.1 \\
\hline 7. Encouragement of renewable & 0 & 37 & 78.7 \\
energy consumption & 1 & 4 & 8.5 \\
& 2 & 6 & 12.8 \\
\hline 8. Water usage information & 0 & 31 & 66.0 \\
& 1 & 6 & 12.8 \\
& 2 & 10 & 21.3 \\
\hline 9. Information concerning the & 0 & 36 & 76.6 \\
materials that are re-cycled or re- & 1 & 3 & 6.4 \\
used & 2 & 8 & 17.0 \\
\hline 10. Any mention of strategies for the & 0 & 38 & 80.9 \\
use of recycling product & 1 & 0 & 0 \\
\hline Pollution \& waste management & 2 & 9 & 19.1 \\
\hline 11. Information about the sources, & 0 & 30 & \\
types \& remedy procedures of & 1 & 4 & 83.8 \\
emissions & 2 & 13 & 27.7 \\
\hline 12. Pollution impacts of & 0 & 41 & 87.2 \\
transportation equipment used for & 1 & 3 & 6.4 \\
logistical purposes & 2 & 3 & 6.4 \\
\hline 13. Environmental impacts of & 0 & 32 & 68.1 \\
principal products \& services & 1 & 3 & 6.4 \\
\hline 14. Discussion on the amount, types & 0 & 33 & 70.2 \\
\hline & 2 & 11 & 23.4 \\
\hline
\end{tabular}




\begin{tabular}{|l|c|c|c|}
\hline Others & & & \\
\hline 15. Any mention of environmental & 0 & 36 & 76.6 \\
accounting policies & 1 & 4 & 8.5 \\
& 2 & 7 & 14.9 \\
\hline 16. Environnemental expenditures & 0 & 37 & 78.7 \\
& 1 & 7 & 14.9 \\
& 2 & 3 & 6.4 \\
\hline 17. Fines/lawsuits/non-compliance & 0 & 11 & 23.4 \\
incidents & 1 & 3 & 6.4 \\
& 2 & 33 & 70.2 \\
\hline 18. Environmental contingent & 0 & 44 & 93.6 \\
liabilities & 1 & 0 & 0 \\
& 2 & 3 & 6.4 \\
\hline
\end{tabular}

Note: $0=$ no disclosure, $1=$ qualitative disclosure, $2=$ quantitative disclosure

\footnotetext{
${ }^{\mathrm{i}}$ Quality of information for this study means information with valid facts and figures varied by independent auditors. As social and environmental information is collected only from annual reports, the information disclosed is considered valid and true. Comment on the quality of disclosure was based on disclosed information. No further cross checking was undertaken to comment on the quality.
} 
AABFJ | Volume 8, no. 1, 2014 